\title{
BOSWELLIA SERRATA ROXB. - A BIOACTIVE HERB WITH VARIOUS PHARMACOLOGICAL ACTIVITIES
}

\author{
SUDHANSHU MISHRA*, RAM SINGH BISHNOI, RAHUL MAURYA, DEEPTI JAIN
}

School of Pharmaceutical Science, Rajiv Gandhi Technical University, Bhopal

Received: 11 August 2020, Revised and Accepted: 18 September 2020

\begin{abstract}
Herbal medicine has become a medicinal as well as the economic aspect of global significance. While the use of these herbal medicines has increased, there are several questions about their consistency, protection, and effectiveness in different countries. Boswellic acid (BA) is one of the active constituents obtained from plant Boswellia serrata (BS) family Burseraceae. The oleoresin gum of the plant is also known as Salai guggul, Indian olibanum, or Indian frankincense. Boswellia species comprises a variety of phytochemical components, essential oil, BA such as keto-BA, beta-BA, or acetyl keto-BA. This variety of constituents isolated from the plant using various extraction processes such as hydrodistillation, percolation, and ultraviolet-assisted extraction or solvent extraction. The active constituent has different biological activities such as antidiuretic, anticancer, antiinflammatory, or antitumor activity. This review seeks to update information on plant BS with its medicinal uses, isolation process in the traditional or Indian system of medicine, and justify its use on modern scientific parameters.
\end{abstract}

Keywords: Natural herb, Boswellia serrata, Terpenic acid, Acetyl keto-boswellic acid, Keto-boswellic acid, Anti-inflammatory agent.

(C) 2020 The Authors. Published by Innovare Academic Sciences Pvt Ltd. This is an open access article under the CC BY license (http://creativecommons. org/licenses/by/4. 0/) DOI: http://dx.doi.org/10.22159/ajpcr.2020.v13i11.39354

\section{INTRODUCTION}

In drug research and growth, natural products are receiving expanded applications. They are chemical rich and can concurrently modulate multiple targets in a complex structure. The use of herbal medicines and phytonutrients continues to expand exponentially all over the world, with many people being exposed to such products in various national health-care settings to tackle different health problems. [1] Boswellia serrata (BS) extract is one of the most effective herbal drugs, which is popularly known as the sallaki, indigenous olibanum of frankincense, and luban. There are more than 25 species grown worldwide such as Boswellia carteri, Boswellia sacra, and Boswellia papyrifera. BS is commonly cultivated in gulf countries such as Saudi Arabia and East Africa. Indian states where it is grown widely include Orissa, Bihar, Gujarat, Rajasthan, Uttar Pradesh, and Madhya Pradesh [2].

The dry exudate from the Boswellia trees bark is a resin of the oleo gum. The extraction of a particular pharmacological active ingredient can be carried out using various extraction methods such as solvent extraction, hydrodistillation, and solvent extraction. This extraction requires various plant parts such as leaves, base, stem, and even a whole Boswellia plant. This extract can be used to cure a number of inflammatory disorders such as Crohn's disease and colitis ulcerations. Both extract and essential oil are used as antiseptic in both mouth washing and asthma with cough care [3].

The resin portion of almost all species of Boswellia consists mostly of boswellic acid (BA) and pentacyclic triterpene. Among all BAs, 11-keto $\beta$-BA and acetyl keto $\beta$-BA are the most potent antiinflammatory agents that selectively inhibit leukotrienes by inhibiting 5-lipoxygenase (5-LOX) in a non-competitive, non-redox, and enzyme directed manner $[4,5]$.

\section{TAXONOMICAL HIERARCHY - [6]}

Kingdom - Plantae.

Subkingdom - Tracheobionta.

Division - Magnoliophyta.

Class - Magnoliopsida.

Order-Sapindales.

Family - Burseraceae
Genus - Boswellia

Species - serrata.

\section{PHARMACOGNOSTICAL FEATURES}

BS is medium to large size deciduous tree as shown in fig. 1 reaching up to 4-5 $\mathrm{m}$ like any other branching tree and having a girth of $1.0-1.5 \mathrm{~m}$ with a spreading flat crown with a diameter of $2.4 \mathrm{~m}$ (avg. 1.5). The height of the plant does not exceed $10 \mathrm{~m}$ and the girth does not go above 1.5-2 $\mathrm{m}$ [5-7]. Table 1 include the various pharmacognostical featurs of plant boswellia.

\section{EXTRACTION PROCESS}

Extraction constitutes the first step in separating the natural materials extracted from the raw material. The general strategies for extracting medicinal plants include maceration, infusion, percolation, digestion, decoction, hot continuous extraction (Soxhlet), aqueous alcoholic extraction by fermentation, countercurrent extraction, microwave-assisted extraction (MAE), ultrasound extraction (sonication), supercritical fluid extraction, and distillation techniques (water distillation, steam distillation, and photonic extraction [with hydrofluorocarbon solvents]. For aromatic plants, hydrowater, and steam distillation), hydrolytic maceration followed by distillation, expression, and effleurage (cold fat extraction) may be employed [7]. Some of the latest extraction methods for aromatic plants include headspace trapping, solid-phase microextraction, protoplast extraction, and microdistillation. As the plant and isolated compounds are well known for their therapeutic properties and use in Ayurveda, each of the extraction methods can be used to achieve the optimum yield of the desired compound for the intended extraction of some particular compound from the plant extract [8].

Various researchers utilized some of the above-mentioned methods for the extraction of the active compounds from Boswellia serrata. Some important description from their study has been enlisted in the following.

\section{THREE-PHASE PARTITIONING (TPP)}

TPP is a fast, effective, and green bioseparation process and often a one-step process to isolate and purify active compounds from complex 
mixtures [9]. This method involves the concept of various techniques such as salting out, isoionic and cosolvent precipitation, and osmolyte and kosmotropic precipitation. The theory of this rapidly evolving method is to combine crude extract with solid salt mostly ammonium sulfate and organic solvent typically t-butanol to achieve three phase $[10,11]$.

\section{PERCOLATION}

Percolation refers to the transfer and filtration of liquid by porous materials. The crude material being extracted is reduced to pieces of suitable size. If necessary, then mixed thoroughly with a portion of the specified solvent and allow to stand for $15 \mathrm{~min}$ [12]. The mixture is moved to a percolator an appropriate quantity of specified solvent is applied to cover entire solid mass and the mixture can percolate slowly at a rate of $1 \mathrm{~mL} / \mathrm{min}$, with $1000 \mathrm{~g}$ of raw material. The matter to be extracted is always covered with a layer of solvent. The residue can be pressed and the fluid obtained is mixed with the percolate and usually concentrated by distillation at low pressure [13].

\section{ULTRASONIC-ASSISTED EXTRACTION (UAE)}

Using ultrasound resulted in better separation of materials in a shorter period and at a lower temperature. The mechanical effect of ultrasound will facilitate the extraction of active plant components by the destruction of the cell walls [14]. Nowadays, UAE has been used to extract pharmaceutically active compounds such as polysaccharides, cellulose, flavonoids, saturated hydrocarbon, fatty acid, ester, and steroids from different parts of the plant. UAE is based on the transmission of mechanical waves, generated by the sequence of cycles described as the combination of high and low pressure, called compression and rarefactions [15].

\section{SUPERACRITICAL FLUID EXTRACTION}

The supercritical condition is the state in which the temperature and pressure of the substance are above the critical values where gas and liquid cannot be separated from one another [16]. The solvent in supercritical state exhibits intermediate physiochemical properties identical to liquid and gas, which improves the solvent extraction capacity [19]. Supercritical carbon dioxide is the most commonly used of the numerous supercritical fluids (ethylene, methane, nitrogen, xenon, or fluorocarbons) used for extraction, as it is non-toxic, nonflammable, non-corrosive, and easy to handle allowing supercritical activity at low pressure and near room temperature $[17,18]$.

\section{HYDRODISTILLATION}

Distillation methods have traditionally been applied in the analysis of plant materials. Hydrodistillation represents a commonly used method of extracting essential oil from plant parts [22]. This method may be further classified into the subcategories of steam distillation, water distillation, and both. The main advantage of this method is that less processing time and higher oil yield. Heat and steam allow the plant material's cells structure to burst and breakdown, thereby releasing essential oils [21,23].

\section{SOXHLET EXTRACTION}

A Soxhlet extractor is a piece of laboratory apparatus designed in 1879 by Franz von Soxhlet. The configuration of the Soxhlet extractor consists of a round bottom flask, siphon tube, distillation path, expansion adapter, condenser, water inlet for cooling, water outlet for cooling, heat source, and thimble [24]. In this method, the powdered sample is enclosed in a porous bag or "thimble" made from a strong filter paper or cellulose, which is placed, is in the thimble chamber of the Soxhlet apparatus [20]. The extraction solvent is taken in the round bottom flask and heated using a heating source like heating mantle [25].

\section{MACERATION}

Maceration is a well-known extraction procedure where phenolic components such as tannins, coloring agents (anthocyanins), and flavor chemicals are extracted from the various parts of the plant [11]. In the maceration process, the plant material is placed in peaces or powder, depending on convenience, in a container full of menstrum and let stand for 3 or more days, shake frequently until complete extraction of plant material. The material is then compressed and pressed to extract all of the excess oil into the resulting solid. The accumulated material is condensed by filtration or decanting. The overall maceration time depends on the type of plant to be extracted, or part of it, or the active ingredient. The most conspicuous ratio is 1:20 herb/liquid [26].

\section{MICROWAVE-ASSISTED}

MAE is a method used in the 1990s to isolate the organic substances from solid materials (microwave digestion has been used in metal analysis for many years). The approach involves simply placing the sample in specialized containers with the solvent and using microwave energy heating the solvent [27]. When collecting samples by MAE, two choices are available: Open vessel and closed vessel, and the decision is primarily influenced by the nature of the solvent used. In general, MAE uses a small quantity of solvents and it is called a "Green" system and also heating occurs in an environmentally selective manner, with even less energy loss [28,29].

\section{STEAM DISTILLATION}

Steam distillation is accomplished by passing dry steam through the plant material, volatilizing, condensing, and collecting the steam volatile compounds in the receivers. Steam distillation has been in use for many years for extracting essential oil [30]. It is a multistage continuous distillation process, where steam is used to extract the oils as a removing gas. Steam is directed through the content of the plant. The hot vapor mixture is collected and condensed to produce a liquid in which the oil and water form two distinct layers. One of these layers is essential oil, which contains oil-soluble compounds, and the other is a hydrolysate or hydrosol, which contains water-soluble components [31].

Table 2 gives a brief idea about various researches on Boswellia extraction process.

\section{CHEMICAL CONSTITUENTS}

Oleo gum resin of BS has numerous active chemical constituents and pharmacologically active elements such as terpenoids and oil [32,33]. The content and composition may vary by species depending on age, resin quality, and geographical condition. The oleo gum contains resins (30-60\%), essential oil (5-10\%), and water-soluble polysaccharides ( $\sim 65 \%$ arabinose, galactose, and xylose) (BS monograph 2008). The essential oil of Salai guggal mainly contains monoterpenoids ( $\alpha$-pinene, cis-verbenol, trans-pinocarveol, borneol, myrcene, phallendrene, cadinene, verbenone, limonene, and a small amount of diterpenes). $\alpha$-pinene $(73.3 \%)$ is the major chemical constituent of monoterpenoid $[34,36]$.

Table 1: Pharmacognostical features of plant

\begin{tabular}{|c|c|c|}
\hline S. No. & Parts & Features \\
\hline 1. & Leaves & $\begin{array}{l}\text { Odd pinnate, length } 30-45 \mathrm{~cm} \text { long, ex-stipulate, } \\
\text { variable in shape, crowded at branch }\end{array}$ \\
\hline 2. & Leaflets & $\begin{array}{l}\text { 8-15 in numbers, ovate or ovate-lanceolate, } \\
\text { rounded base, almost sessile, mostly pubescent }\end{array}$ \\
\hline 3. & Flower & $\begin{array}{l}\text { Bisexual, axillary racemes, or panicles at the top } \\
\text { of the branches }\end{array}$ \\
\hline 4. & Calyx & $\begin{array}{l}\text { Smaller, pubescent outside, 5-6 lobed broadly } \\
\text { triangular-ovate }\end{array}$ \\
\hline 5. & Petals & $\begin{array}{l}5 \mathrm{~mm} \text { long oblong-ovate with the basal disk, } \\
\text { white- pink in color }\end{array}$ \\
\hline 6. & Fruits & $\begin{array}{l}\text { Cotyledons, trifid, drupe, } 1.25 \mathrm{~cm} \text { long trigonous } \\
\text { obovoid type }\end{array}$ \\
\hline 7. & Seeds & $\begin{array}{l}\text { Heart-shaped, attached to the inner angle of the } \\
\text { compressed and multified cotyledons }\end{array}$ \\
\hline
\end{tabular}


Table 2: Extraction techniques with their conditions

\begin{tabular}{|c|c|c|c|c|c|}
\hline S. No. & Technique & Solvent & Condition & Active constituent & Max. yield \\
\hline 1. & Three-phase partitioning & t-butanol dichloromethane & $3-4 \mathrm{~h}$ & Acetyl keto-boswellic acid & $35-40 \%$ \\
\hline 2. & Percolation & $\begin{array}{l}\text { Ethanol Pet. ether Water } \\
\text { Acetone } \\
\text { Methanol }\end{array}$ & $\begin{array}{l}50-1000 \mathrm{ml} \\
\text { solvent used } 24 \mathrm{~h}\end{array}$ & Boswellic acid & $25-30 \%$ \\
\hline 3. & Ultrasonic assisted & Pet. ether Ethanol Methanol & $\begin{array}{l}50-300 \mathrm{ml} \\
\text { solvent } 2-3 \mathrm{~h} \\
20-25 \mathrm{kHz} \\
150-200 \mathrm{~W}\end{array}$ & Acetyl keto-boswellic acid & $40-60 \%$ \\
\hline 4. & Supracritical fluid extraction & Carbon dioxide & $\begin{array}{l}100-250 \text { bars } \\
40-45^{\circ} \mathrm{C}\end{array}$ & Boswellic acid & $45-50 \%$ \\
\hline 5. & Soxhlet extraction & $\begin{array}{l}\text { Ethanol Hydroalcohols Pet. } \\
\text { ether Hexane Methanol }\end{array}$ & $\begin{array}{l}40-70^{\circ} \mathrm{C} \\
10-24 \mathrm{~h}\end{array}$ & $\begin{array}{l}\text { Carbohydrates } \\
\text { Tannins Glycoside Terpenes }\end{array}$ & $45-55 \%$ \\
\hline 6. & Hydrodistillation & Distilled water & $\begin{array}{l}300-500 \mathrm{ml} \\
3-8 \mathrm{~h} \\
160^{\circ} \mathrm{C}\end{array}$ & Essential oil & $5-10 \%$ \\
\hline 7. & Maceration & $\begin{array}{l}\text { Water Ethanol } \\
\text { Hydroalcohols }\end{array}$ & $\begin{array}{l}1: 1 \text { ration } \\
6-12 \mathrm{~h}\end{array}$ & Boswellic acid & \\
\hline $\begin{array}{l}8 . \\
9 .\end{array}$ & $\begin{array}{l}\text { Microwave assisted } \\
\text { Steam distillation }\end{array}$ & $\begin{array}{l}\text { Water } \\
\text { Distilled water }\end{array}$ & $\begin{array}{l}8-10 \mathrm{~h} \\
1 \mathrm{l} \\
100^{\circ} \mathrm{C}\end{array}$ & $\begin{array}{l}\text { Essential oils } \\
\text { Boswellic acid }\end{array}$ & $\begin{array}{l}2-5 \% \\
3-10 \%\end{array}$ \\
\hline
\end{tabular}

Table 3: Identification test for various active constituents

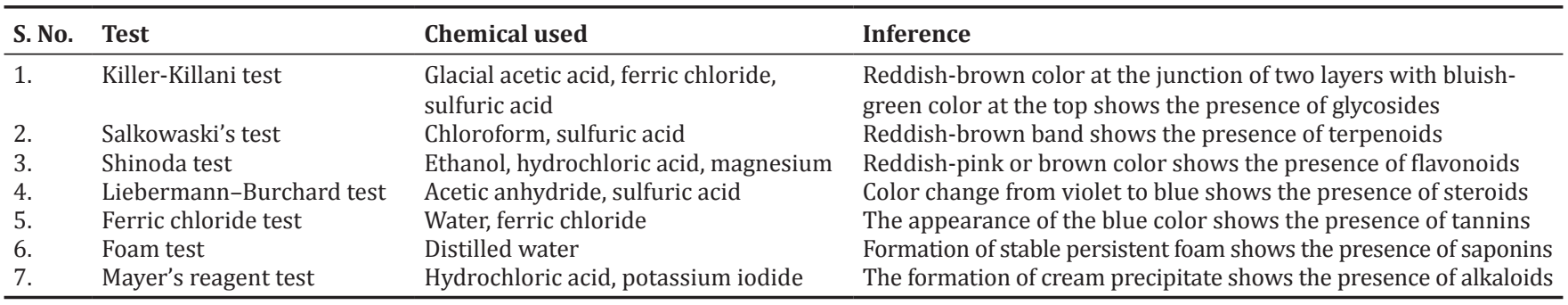

Table 4: Mechanism of action along with some formulation

\begin{tabular}{|c|c|c|c|}
\hline S. No. & Activity & MOA & Formulations \\
\hline 1. & $\begin{array}{l}\text { Anti- } \\
\text { inflammatory }\end{array}$ & $\begin{array}{l}\downarrow 5 \text {-LO, } \downarrow 5 \text {-LOX } \downarrow \text { COX-2 } \\
\downarrow \text { Pro-inflammatory } \\
\text { cytokines } \\
\downarrow \text { TNF- } \alpha, \downarrow \text { IL- } \beta\end{array}$ & Tablet/herbal gel/ \\
\hline 2. & Antimicrobial & $\begin{array}{l}\downarrow \text { Antimicrobial } \\
\text { peptide LL-37 }\end{array}$ & $\begin{array}{l}\text { Gel/cream/silver } \\
\text { nanoparticle }\end{array}$ \\
\hline 3. & Anticancer & $\begin{array}{l}\downarrow N F-\kappa B \text { AKBA } \\
\downarrow \text { VEGFR2 } \\
\text { Demethylation } \\
\text { and reactivation of } \\
\text { methylation silenced } \\
\text { tumor suppressor } \\
\text { genes }\end{array}$ & $\begin{array}{l}\text { Solid lipid } \\
\text { nanoparticle }\end{array}$ \\
\hline 4. & $\begin{array}{l}\text { Improving } \\
\text { memory }\end{array}$ & $\uparrow \mathrm{GSH}$ content & Tablet \\
\hline 5. & Antioxidant & $\begin{array}{l}\text { Regulating the Nrf2/ } \\
\text { HO-1 pathway }\end{array}$ & $\begin{array}{l}\text { Silver } \\
\text { nanoparticles }\end{array}$ \\
\hline
\end{tabular}

5-LO: 5-Lipoxygenase, HLE: Human leukocyte elastase, 5-LOX: 5-Liperoxidase, TNF- $\alpha$ : Tumor necrosis factor- $\alpha$, (IL- $\beta$ ): Interleukin- 1 beta, COX-2:

Cyclooxygenase-2, NF- kB: Nuclear factor-kappa B, VEGFR2: Vascular endothelial growth factor receptor 2, GSH: Glutathione, Nrf-2: The nuclear factor erythroid 2 (NFE2)-related factor 2, HO-1: Heme oxygenase-1

B. serrata gum resin contains 12 different types of BA but the six major acids include the $\alpha$ - and $\beta$-BA, acetylated $\alpha$ - and $\beta$-BA, 11-keto $\beta$-BA (KBA), and 3-Acetyl keto- $\beta$-BA (AKBA) [35] which are susceptible to an inflammatory enzyme $[37,38]$. Chemical structure of some major terpenic acids is shown in Fig. 2.

\section{PHYTOCHEMICAL EVALUATION}

Phytoconstituents are the bioactive chemical compounds present in the plants $[39,40]$. These phytoconstituents work with nutrients and fibers to form an essential part of the protection mechanism against specific diseases and stress conditions. Qualitative analysis as well as quantitative phytochemical analysis are the important application of biomedicine in pharmaceutical industries [41,42]. The phytochemical analysis was very useful in identifying chemical compounds in plant material which led to their quantitative estimate and the position of the pharmacy. There are some tests mentioned in Table 3, whichhelp to screening the presence of active compound in the plant.

\section{APPLICATIONS}

\section{ANTI-INFLAMMATORY}

Arthritis is characterized by systemic inflammation, which can be related to pain, rigidity, and joint damage. Arthritis can be of different types which directly affect more than 1 joints such as fingers, ankles, and elbow depending on the type of arthritis. Gum resin extracts of $B$. serrata have been traditionally used in folk medicine for centuries to treat various chronic inflammatory diseases [45]. The data of numerous scientific studies support the claim that $B$. serrata possesses potent anti-inflammatory and anti-atherosclerotic activity. Su et al., 2011, have reported the anti-inflammatory activity as well as the analgesic effect of BA with a combination of Myrrha [43]. Agarwal et al., 2013, have prepared a herbal gel containing Boswellia extract for the treatment of arthritis. Some study reported that BA is as a direct 5-LO inhibitor, suppressing the synthesis of 5-LO products in common in vitro models [44]. Natural Boswellia extract compounds also exhibit anti-inflammatory properties in human peripheral mononuclear blood cells and mouse macrophages by inhibiting tumor necrosis factor- 
alpha (TNF- $\alpha$ ), interleukin-1 beta (IL-1 $\beta$ ), NO and mitogen-activated protein kinases, and incensole acetate, a novel anti-inflammatory

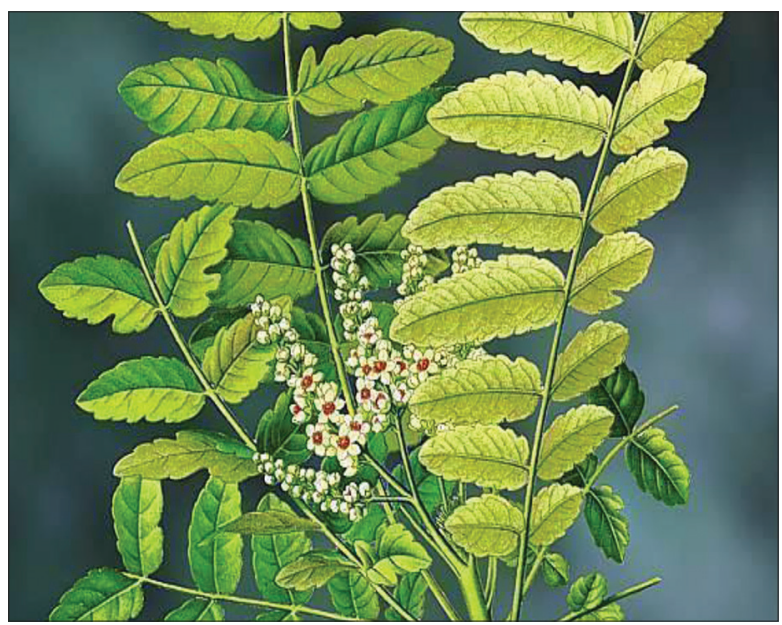

Fig. 1: Boswellia serrata roxbH compound isolated from Boswellia resin inhibits nuclear factor-kappa B activation [46,47].

\section{ANTIMICROBIAL}

Various studies have reported that crude extract of Boswellia species contains an antimicrobial agent that stops the further growth of microbes [60]. Kora et al., 2012, to the prepared silver nanoparticle of aqueous extract of Boswellia which acts as an antimicrobial agent on both Gram-positive and Gram-negative bacteria [48]. Ismail et al., 2014, have reported the antimicrobial activity of frankincense on both Grampositive and Gram-negative bacteria. Other studies also reported that the gum resin of frankincense is active against Staphylococcus aureus, Escherichia coli, Klebsiella species, Pseudomonas aeruginosa, Proteus mirabilis, and Bacillus subtilis [49]. In addition to this, De Rapper et al., 2012, have reported B. serrata EO $\alpha$-pinene (38.41\%) and myrcene (15.21\%), while Commiphora myrrha E0 was characterized by a high content of furanoeudesma-1,3-diene (17.65\%) followed by curzerene $(12.97 \%), \beta$-element $(12.70 \%)$, and germacrene- $\beta(12.15 \%)$ having both an antimicrobial and antifungal activity [50]. Vahabi et al., 2020, have reported antimicrobial activity of BS extract by disk diffusion or well plate method and broth microdilution method [51].<smiles>CC1CCC2(C)C(C)CCC3C4CCC5(CCC(C)(C)CC45)CCC32C1</smiles>

Alpha-Boswellic acid

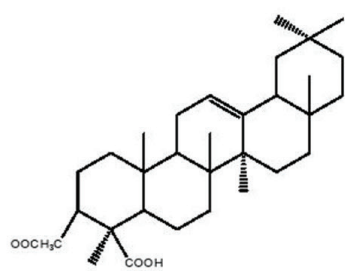

Acetyl-alpha-Boswellic acid

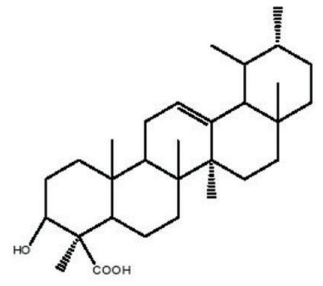

B-Boswellic acid

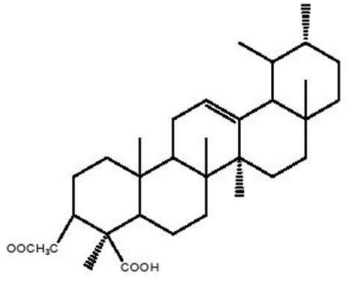

Acetyl-B-Boswellic acid<smiles>CC1CCC2CCC3(C(C)CCC4(C)C5CCC6(C)CCC(C)(C)C6C5CCC43C)C2(C)C1</smiles>

9,11-dehydro-alpha-Boswellic acid<smiles>CC[C@H]1CCC2(C)C3CC=C4C5CC(C)(C)CCC5CC[C@]4(C)C3CCC2C1(C)C</smiles>

Acetyl-9,11-dehydro-alpha-Boswellic acid

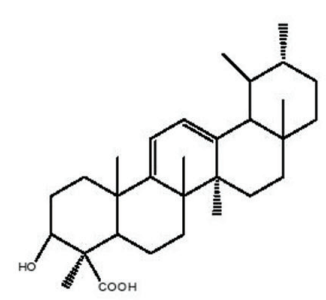

9,11-dehydro- $\beta$-Bos wellic acid

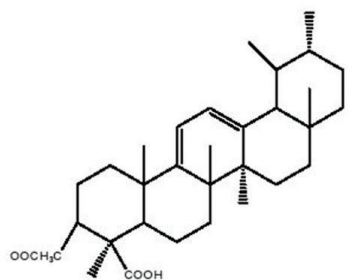

Acetyl-9,11-dehydro-B-Boswellic acid<smiles>CC1C2CCC3(C)C(C)C4C(=CC(=O)C5C4(C)CCC4C5(C)CCC(O)[C@@]4(C)O)[C@@]3(C)CCC2(C)CC[C@@H]1C</smiles>

11-keto-B-Boswellic acid

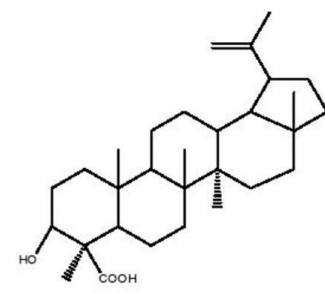

Lupeolic acid

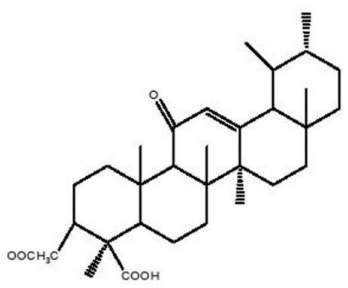

Acetyl-11-keto- $\beta$-Boswellic acid

Fig. 2: Chemical structure of various terpenic acids 


\section{ANTIVIRAL}

According to the researcher, Boswellia species also possess having an antiviral activity. Arora et al, 2020, have reported the antiviral activity of frankincense against CHIKV and both compounds blocked the entry of lentiviral vectors and prevented in vitro infection with CHIKV. Similarly, vesicular stomatitis virus particles and viral infections were also inhibited to the same degree, suggesting a strong antiviral activity [52]. Badria et al., 2003, have also reported antiviral activity of different constituents obtained from Boswellia species against herpes simplex type I virus and were able to reduce the number of the plaques by $100 \%$ with a minimum antiviral concentration at $20 \mu \mathrm{g} / \mathrm{ml}$ and followed by acetyl-11-keto- $\beta$-BA $(75 \%$ inhibition at $20 \mu \mathrm{g} / \mathrm{ml}), \beta$-boswellic and total alcoholic extract (50\% inhibition at $40 \mu \mathrm{g} / \mathrm{ml})$, acetyl- $\beta$-boswellic and 11-keto- $\beta$-boswellic $(75 \%$ inhibition at $80 \mu \mathrm{g} / \mathrm{ml}$ ), 3-hydroxytirucallic acid, 3-oxo-tirucallic acid, acetyl- $\alpha-B A$, and total volatile oil (50\% inhibition at $80 \mu \mathrm{g} / \mathrm{ml})$. On the other hand, gum, palmitic acid, and lupeol reduced the number of plaques by $25 \%$ at relatively higher concentrations [53]. This shows that BS also exhibit antiviral activity.

\section{ANTICANCER AND ANTITUMOR}

BA anticancer activity has been documented in many studies. Takahash et al., 2012, have reported AKBA as a chemoprotective agent in colorectal cancerous cells by modulating specific micro-RNA pathways [54]. Schmiech et al., 2019, have reported the correlation of boswellic and lupeolic acid contents with TNF- $\alpha$, IL-1 $\beta$, IL-6, IL-8, and IL-10 inhibition. They also exhibited toxicity against the human triplenegative breast cancer cell lines MDA-MB-231, MDA-MB-453, and CAL-51 in vitro [55]. Khan et al., 2016, reported that BA significantly inhibited the ascetic and solid Ehrlich tumor model [56]. The inhibition was observed with reduced ascetic volume, solid tumor volume, and body weight when compared to that of control mice. A treatment also increased the survival of tumor-bearing mice. Vascular endothelial growth factor and TNF- $\alpha$ levels were decreased, whereas the IL-12 levels were increased with BA treatment at $25 \mathrm{mg} / \mathrm{kg}$. Further, results on the decrease in the peritoneal angiogenesis and microvessel density showed the antiangiogenic potential $[57,58]$.

\section{ANTIDEPRESSANT ACTIVÌTY}

The extract obtain from the plant is used as aroma therapy also in various tea formulations. B. serrata has been reported to be successful on an acute depression scale. Prabhakar et al., 2013, illustrated this at a dosage of $100 \mathrm{mg} / \mathrm{kg}$, Boswellia has significant antidepressant efficacy in acute stress experiments and reduces the immobility time in the experimental forced swim model [59]. B. serrata, traditionally important medicinal plant, proved to be a bacteriostatic agent.

\section{ANTI-ALZHEIMER'S ACTIVITY}

Alzheimer's disease (AD) is a neurodegenerative, chronic condition. Increased oxidative stress in $\mathrm{AD}$ has proved to be a popular and early feature [60]. Medicinal plants with antioxidant activity have widely been used in treating a variety of human diseases. Yassin et al., 2013, have reported that Boswellia has the potential to treat the $\mathrm{AlCl}_{3}-$ induced Alzheimer by elevation of Ach level and reduction of AchE activity in brain homogenates [61,62]. Beheshti et al., 2016, have also reported that frankincense has the potential to improve dementia type of $\mathrm{AD}$ induced by i.c.v injection of streptozotocin in a time-dependent manner [66].

\section{MISCELLANEOUS}

Various study also have found that the boswellic acid is used in treatment of various disease mention in Table 4 including that, prepared a solid lipid nanoparticle combined with frankincense and myrrh oil which increased the antitumor efficacy in H22-bearing Kunming mice [63]. Togni et al., 2014, also prepared a topical formulation for the treatment of psoriasis and eczema [64]. Taghizadeh et al., 2017, were performed a study to investigate the effect of a table containing BS extract and
Melissa officinalis extract on the memory of the older adults and found that they can be beneficial on the improvement of memory [65].

\section{SAFETY AND BIOAVAILABILITY ENHANCEMENT OF FRANKINCENSE}

Based on the observations and results obtained from different research, it can be stated that the B. serrata given to the animals demonstrated no mortality as well as any adverse effect on animal health [67]. Boswellia is usually taken orally as a capsule, tablet, or decoction of its bark. The suggested dosage is based on current historical experience or studies. It is not currently known whether the appropriate dosage is for a balance between protection and effectiveness. The production of Boswellia products differs from one product to another and this makes standardization much more complicated. It is important to remember that most of the trials used different products manufactured by different suppliers, so clinical results could not be comparable $[68,69]$. In regard of the relatively low plasma and brain levels of BAs, and as a consequence of their inability to inhibit 5-LOX in whole blood, the abrogation of LTB4 synthesis in vivo by frankincense extracts remains unclear. Several methods have been used to explore the potential pharmacological properties of various BAs to increase its bioavailability [70]. Some studies have endeavored to increase BAs' bioavailability using a regular meal. Furthermore, an improvement in their uptake was observed when it was administered with anionic drugs $[71,72]$. In addition, various approaches such as lecithin delivery process (Phytosome R); nanoparticle delivery mechanisms such as liposomes, emulsions, rigid lipid nanoparticles, nanostructured lipid carriers, micelles, and poly(lactic-co-glycolic acid) nanoparticles; and synthetic derivatization of BA have been modified to overcome this problem [73-75].

\section{BRANDED FORMULATION CONTAINING BS}

In addition to its use in religious ceremonies, olibanum has been used as an essential fixative in perfumes, soaps, creams, lotions, and detergents, with an oriental emphasis in its aroma, in leading perfume and cosmetics products [76]. A third market for olibanum was developed by the interests of pharmaceutical firms. Some of the branded formulations containing B. serrata available in the market are as follows [77]:

1. In 1991, Boswellin ${ }^{\circledR}$, a Sabinsa Company registered trademark, was introduced to the US and European markets. This is available in pills or tablets, as well as in a cream of capsaicin that relieves calming discomfort. BA drugs range from 150 to $250 \mathrm{mgs} /$ capsules or tablets and are taken orally 2-3 times a day. Shallaki ${ }^{\circledR}$, contains $125 \mathrm{mg}$ B. serrata in each capsule manufactured by Himalayan Drug Company, Makali, Bengaluru, as Licensed User of the Trade Mark owned by MMI Corporation, has excellent anti-inflammatory and analgesic properties, useful in relieving joint pains. Sixty capsule costs Rs. 75/- and the dose is 1 capsule twice daily (Batch No. F297001G). The website of the company is www.himalayahealthcare.com

2. Niltan ${ }^{\circledR}$ is a cream for external use in a $15 \mathrm{~g}$ container. It is a mixture of active herbal extracts (boswellin, arbutin, liquorice extract, and coriander seed oil in a cream base) developed by Dr. Reddy's Laboratories Limited, Hyderabad. It decreases the enzyme tyrosinase activity within the skin, thus reducing the development of melanin, leading to a decrease in the formation of dark skin

3. Rheumatic- $X^{\circledR}$ includes, in addition to a variety of ingredients, $20 \mathrm{mg}$ "Shallaki" made by Sunrise Herbals, Varanasi (U.P., India), intended for rheumatoid, gouty, osteoarthritis, and sciatic pain, two capsules twice daily or as instructed by the physician

4. $\operatorname{Colox}^{\circledR}$ is a herbal capsule that blocks COX-2 and 5-LOX reducing inflammation, joint pain, and stiffness; 901 mg natural extracts; 120 veg. capsules; zero side effects; which is suitable for Jains, vegans, and vegetarians the capsule is registered by the Vegan Society - UK

5. Frankincense ${ }^{\circledR}$ serrata an essential oil is steam obtained from a tree's gum resin by plant therapy essential oil. It has been used by native peoples as an incense, medicine, and in cosmetics for thousands of years. It is used for a blend which helps to promote clear respiration and is used in other aroma therapies. 


\section{CONCLUSION}

BA has gained widespread exposure for its various health advantages which mainly tend to work through anti-inflammatory mechanism. They are also used as expectorant, antiseptic, and antineurotic drug. Alcohol extract from frankincense inhibit the growth of bacteria as well as fungi. Boswellia preparation like topical preparation inhibits 5-LO and prevents the formation of leukotrienes. There are various formulations which are used in the treatment of chronic disease like cancer. The net goal regarding the different constituents of BS is to understand the drug-drug interaction, molecular mechanism, and also strategies to improve their pharmacokinetic profile.

\section{AUTHORS' CONTRIBUTIONS}

All the authors have contributed to the literature review preparation, and editing of the manuscript.

\section{CONFLICTS OF INTEREST}

All authors have none to declare.

\section{AUTHORS' FUNDING}

No funding source from any organization.

\section{REFERENCES}

1. Ansari SH, Islam F, Sameem M. Influence of nanotechnology on herbal drugs: A review. J Adv Pharm Technol Res 2012;3:142.

2. Kohoude MJ, Gbaguidi F, Agbani P, Ayedoun MA, Cazaux S, Bouajila J. Chemical composition and biological activities of extracts and essential oil of Boswellia dalzielii leaves. Pharm Biol 2017;55:33-42.

3. Ali NA, Wurster M, Arnold N, Teichert A, Schmidt J, Lindequist U, et al. Chemical composition and biological activities of essential oils from the oleogum resins of three endemic soqotraen Boswellia species. Rec Nat Prod 2008;2:6.

4. Hussain H, Al-Harrasi A, Al-Rawahi A, Hussain J. Chemistry and biology of essential oils of genus Boswellia. Evid Based Complement Alternat Med 2013;2013:140509.

5. Al-Harrasi A, Hussain H, Csuk R, Khan HY. Taxonomy of Boswellia tree, traditional medicinal uses of frankincense and historical aspects of boswellic acids. In: Chemistry and Bioactivity of Boswellic Acids and Other Terpenoids of the Genus Boswellia. Netherlands: Elsevier; 2018. p. 1.

6. Al-Harrasi A, Khan AL, Asaf S, Al-Rawahi A. Biology of Genus Boswellia. Berlin, Germany: Springer; 2019.

7. Gupta A, Naraniwal M, Kothari V. Modern extraction methods for preparation of bioactive plant extracts. J Nat Appl Sci 2012;1:8-26.

8. Azmir J, Zaidul IS, Rahman MM, Sharif KM, Mohamed A, Sahena F, et al. Techniques for extraction of bioactive compounds from plant materials: A review. Food Eng Rew 2013;117:426-36.

9. Niphadkar SS, Bokhale NB, Rathod VK. Extraction of acetyl 11-keto$\beta$-boswellic acid (AKBA) from Boswellia serrata plant oleo gum resin using novel three phase partitioning (TPP) technique. J Appl Res Med Aroma 2017;7:41-7.

10. Patil SS, Rathod VK. Synergistic effect of ultrasound and three phase partitioning for the extraction of curcuminoids from Curcuma longa and its bioactivity profile. Process Biochem 2020;93:85-93.

11. Sharma N, Bhardwaj V, Singh S, Ali SA, Gupta DK, Paul S, et al. Simultaneous quantification of triterpenoic acids by high performance liquid chromatography method in the extracts of gum resin of Boswellia serrata obtained by different extraction techniques. Chem Cent J 2016;10:49.

12. Zhang QW, Lin LG, Ye WC. Techniques for extraction and isolation of natural products: A comprehensive review. Chi Med 2018;13:20.

13. Afsar V, Reddy YM, Saritha KV. In vitro antioxidant activity and antiinflammatory activity of methanolic leaf extract of Boswellia serrata. Int J Life Sci Biotechnol Pharm Res 2012;4:15-23.

14. Niphadkar SS, Rathod VK. Extraction of acetyl 11-keto- $\beta$-boswellic acids (AKBA) from Boswellia serrata using ultrasound. Sep Sci Technol 2017;52:997-1005.

15. Routray W, Orsat V. Microwave-assisted extraction of flavonoids: A review. Food Bioproc Tech 2012;5:409-24.

16. Niphadkar SS, Rathod VK. Optimization of ethanol modified supercritical fluid extraction (SFE) of acetyl 11 keto $\beta$ boswellic acid
(AKBA) from Boswellia serrata using box-Behnken experimental design. Biocatal Agric Biotechnol 2018;13;304-10

17. Chou YC, Suh JH, Wang Y, Pahwa M, Badmaev V, Ho CT, et al. Boswellia serrata resin extract alleviates azoxymethane (AOM)/ dextran sodium sulfate (DSS)-induced colon tumorigenesis. Mol Nutr Food Res 2017;61:1600984.

18. Pandey RS, Singh BK, Tripathi YB. Extract of gum resins of Boswellia serrata L. Inhibits lipopolysaccharide induced nitric oxide production in rat macrophages along with hypolipidernic property. Indian J Exp Biol 2017;43:509-16.

19. Belsner K, Büchele B, Werz U, Simmet T. Structural analysis of 3- $\alpha$-acetyl-20 (29)-lupene-24-oic acid, a novel pentacyclic triterpene isolated from the gum resin of Boswellia serrata, by NMR spectroscopy. Magn Reson Chem 2003;41:629-32.

20. Sharma A, Bhatia S, Kharya MD, Gajbhiye V, Ganesh N, Namdeo AG, et al. Anti-inflammatory and analgesic activity of different fractions of Boswellia serrata. Int J Phytomed 2010;2:94-99.

21. Ahmed HH, Abd-Rabou AA, Hassan AZ, Kotob SE. Phytochemical analysis and anti-cancer investigation of Boswellia serrata bioactive constituents in vitro. Asian Pac J Cancer Prev 2015;16:7179-88.

22. Lin HK, Suhail MM, Fung KM, Woolley CL, Young DG. Extraction of biologically active compounds by hydrodistillation of Boswellia species gum resins for anti-cancer therapy. OA Alternat Med 2013;1:4.

23. Kasali AA, Adio AM, Oyedeji AO, Eshilokun AO, Adefenwa M. Volatile constituents of Boswellia serrata Roxb. (Burseraceae) bark. Flavour Frag J 2002;17:462-4

24. Mishra NK, Bstia S, Mishra G, Chowdary KA, Patra S. Anti-arthritic activity of Glycyrrhiza glabra, Boswellia serrata and their synergistic activity in combined formulation studied in Freund's adjuvant induced arthritic rats. Int J Pharm Educ Res 2011;2:92.

25. Singh HP, Yadav IK, Chandra D, Jain DA. In vitro antioxidant and free radical scavenging activity of different extracts of Boerhavia diffusa and Boswellia serrata. Int J Pharm Sci Res 2012;3:503-11.

26. Kumar D, Kumar V, Jalwal P. Boswellic acid-potential tumors suppressant terpenoid-photochemistry, extraction and isolation methods-a comprehensive review study. J Pharmacogn Phytochem 2016;5:231.

27. Turk M, Mathe C, Fabiano-Tixier AS, Carnaroglio D, Chemat F. Parameter optimization in microwave-assisted distillation of frankincense essential oil. CR Chim 2018;21:622-7.

28. Niphadkar S, Rathod V. Optimization of microwave-assisted extraction of acetyl 11 keto $\beta$ boswellic Acid (AKBA) from Boswellia Serrata by using orthogonal array design (OAD). J Biol Prod Nat 2018;8:90-103.

29. Manisha DR, Merugu R, Vijaybabu AR, Rudra MP. Microwave assisted biogenic synthesis of silver nanoparticles using dried seed extract of Coriandrum sativum, characterization and antimicrobial activity. Int $\mathrm{J}$ Chem Tech Res 2014;6:3957-61.

30. Ayub MA, Hanif MA, Sarfraz RA, Shahid M. Biological activity of Boswellia serrata Roxb. Oleo gum resin essential oil: Effects of extraction by supercritical carbon dioxide and traditional methods. Int $\mathrm{J}$ Food Prop 2018;21:808-20.

31. Hasegawa T, Kikuchi A, Saitoh H, Yamada H. Structure and properties of constituents in hexane extract of frankincense. J Essent Oil Res 2012;24:593-8.

32. Alam M, Khan H, Samiullah L, Siddique KM. A review on phytochemical and pharmacological studies of Kundur (Boswellia serrate Roxb ex Colebr.)-a unani drug. J Appl Pharm Sci 2012;2:148-56

33. Lemenith M, Teketay D. Frankincense and myrrh resources of Ethiopia: II. Medicinal and industrial uses. SINET Ethiop J Health Sci 2003;26:161-72.

34. Sharma A, Chhikara S, Ghodekar S, Bhatia S, Kharya M, Gajbhiye V, et al. Phytochemical and pharmacological investigations on Boswellia serrata. Pharmacogn Rev 2009;3:206.

35. Satpute KL, Kalyankar TM. Development and evaluation of herbal cream for the treatment of acne. J Pharmacogn Phytochem 2019;8:2618-24.

36. Alluri VK, Kundimi S, Sengupta K, Golakoti T, Kilari EK. An antiinflammatory composition of Boswellia serrata resin extracts alleviates pain and protects cartilage in monoiodo acetate-induced osteoarthritis in rats. Evid Based Complement Alternat Med 2020;2020:7381625.

37. Hüsch J, Gerbeth K, Fricker G, Setzer C, Zirkel J, Rebmann H, et al. Effect of phospholipid-based formulations of Boswellia serrata extract on the solubility, permeability, and absorption of the individual boswellic acid constituents present. J Nat Prod 2012;75:1675-82.

38. Gerbeth K, Hüsch J, Fricker G, Werz O, Schubert-Zsilavecz M, Abdel-Tawab M. In vitro metabolism, permeation, and brain 
availability of six major boswellic acids from Boswellia serrata gum resins. Fitoterapia 2013;84:99-106.

39. Srujana TS, Konduri RB, Rao BS. Phytochemical investigation and biological activity of leaves extract of plant Boswellia serrata. J Pharm Innov 2012;1:22

40. Bhutada SA, Farhan MM, Dahikar SB. Preliminary phytochemical screening and antibacterial activity of resins of Boswellia serrata Roxb. J Pharmacogn Phytochem 2017;6:182-5.

41. Shaikh JR, Patil MK. Qualitative tests for preliminary phytochemical screening: An overview. Int J Chem Stud 2020;8:603-8.

42. Ohemu TL, Agunu A, Chollom SC, Okwori VA, Dalen DG, Olotu PN. Preliminary phytochemical screening and antiviral potential of methanol stem bark extract of Enantia Chlorantha Oliver (Annonaceae) and Boswellia dalzielii Hutch (Burseraceae) against Newcastle disease in Ovo. Eur J Med Plants 2018;25:1-8.

43. Su S, Hua Y, Wang Y, Gu W, Zhou W, Duan JA, et al. Evaluation of the anti-inflammatory and analgesic properties of individual and combined extracts from Commiphora myrrha, and Boswellia carterii. J Ethnopharmacol 2012;139:649-56.

44. Agrawal PO, Baajpayee ME, Singh SP. Formulation and evaluation of herbal gel containing Boswellia serrata, curcuma longa extract and oil of wintergreen for rheumatoid arthritis. Int Bull Drug Res 2013;2:31-40

45. Asante-Kwatia E, Mensah AY, Baidoo MF. Analgesic and antiinflammatory effect of Ghanaian medicinal plants. In: Medicinal Plants-use in Prevention and Treatment of Diseases. United Kingdom: IntechOpen; 2020.

46. Andor BC, Cerbu S, Barattini DF, Dogaru DE, Dulgheru O, Guadagna $\mathrm{S}$, et al. Pilot, open and non-controlled trial to assess the objective parameters which correlate knee mobility with pain reduction in patients affected by knee osteoarthritis and treated with oral hyaluronic acid. Rev Chim 2013;70:3364-71.

47. Catanzaro D, Rancan S, Orso G, Dall'Acqua S, Brun P, Giron MC, et al. Boswellia serrata preserves intestinal epithelial barrier from oxidative and inflammatory damage. PLoS One 2015;10:e0125375.

48. Kora AJ, Sashidhar RB, Arunachalam J. Aqueous extract of gum olibanum (Boswellia serrata): A reductant and stabilizer for the biosynthesis of antibacterial silver nanoparticles. Process Biochem 2012;47:1516-20.

49. Ismail SM, Aluru S, Sambasivarao KR, Matcha B. Antimicrobial activity of frankincense of Boswellia serrata. Int J Curr Microbiol App Sci 2014:3:1095-101.

50. De Rapper S, Van Vuuren SF, Kamatou GP, Viljoen AM, Dagne E. The additive and synergistic antimicrobial effects of select frankincense and myrrh oils-a combination from the pharaonic pharmacopoeia. Lett Appl Microbiol 2012;54:352-8.

51. Vahabi S, Hakemi-Vala M, Gholami S. In vitro antibacterial effect of hydroalcoholic extract of Lawsonia inermis, Malva sylvestris, and Boswellia serrata on Aggregatibacter actinomycetemcomitans. Adv Biomed Res 2019;8:22.

52. Arora K, Tomar PC, Kumari P, Kumari A. Medicinal alternative for chikungunya cure: A herbal approach. J Microbiol Biotechnol Food Sci 2020;9:970-8

53. Badria FA, Abu-Karam M, Mikhaeil BR, Maatooq GT, Amer MM. Anti-herpes activity of isolated compounds from frankincense. Biosci Biotech Res Asia 2016;1:1-10

54. Takahashi M, Sung B, Shen Y, Hur K, Link A, Boland CR, et al. Boswellic acid exerts antitumor effects in colorectal cancer cells by modulating expression of the let-7 and miR-200 microRNA family. Carcinogenesis 2012;33:2441-9.

55. Schmiech M, Lang SJ, Ulrich J, Werner K, Rashan LJ, Syrovets T, et al. Comparative investigation of frankincense nutraceuticals: Correlation of boswellic and lupeolic acid contents with cytokine release inhibition and toxicity against triple-negative breast cancer cells. Nutrients 2019;11:2341.

56. Khan MA, Ali R, Parveen R, Najmi AK, Ahmad S. Pharmacological evidences for cytotoxic and antitumor properties of boswellic acids from Boswellia serrata. J Ethnopharmacol 2016;191:315-23.

57. Csuk R, Niesen-Barthel A, Barthel A, Kluge R, Ströhl D. Synthesis of an antitumor active endoperoxide from 11-keto- $\beta$-boswellic acid. Eur J Med Chem 2010;45:3840-3

58. Yadav VR, Prasad S, Sung B, Gelovani JG, Guha S, Krishnan S, et al. Boswellic acid inhibits growth and metastasis of human colorectal cancer in orthotopic mouse model by downregulating inflammatory, proliferative, invasive and angiogenic biomarkers. Int $\mathrm{J}$ Cancer 2012;130:2176-84

59. Prabhakar A, Chandrashekar R, Rao SN. Evaluation of antidepressant activity of Boswellia serrata in Swiss albino mice by forced swim test. Int J Univ Pharm Bio Sci 2013;2:417-24.

60. Haghaei H, Soltani S, Hosseini SR, Rashidi MR, Karima S. Boswellic acids as promising leads in drug development against Alzheimer's disease. Pharm Sci 2020;2020:2-41.

61. Yassin N, El-Shenawy S, Mahdy KA, Gouda N, Marrie AE, Farrag A, et al. Effect of Boswellia serrata on Alzheimer's disease induced in rats. J Arab Soc Med Res 2013;8:1-11.

62. Ibrahim BM. Experimental Study of the Effects of Boswellia serrata and Ginger (Zingiber officinale) on Alzheimer's Disease Induced in Rats. Calcutta: CU Theses; 2012.

63. Shi F, Zhao JH, Liu Y, Wang Z, Zhang YT, Feng NP. Preparation and characterization of solid lipid nanoparticles loaded with frankincense and myrrh oil. Int J Nanomedicine 2012;7:2033.

64. Togni S, Maramaldi G, Di Pierro F, Biondi M. A cosmeceutical formulation based on boswellic acids for the treatment of erythematous eczema and psoriasis. Clin Cosmet Investig Dermatol 2014:7:321.

65. Taghizadeh M, Maghaminejad F, Aghajani M, Rahmani M. The effect of tablet containing Boswellia serrata and Melissa officinalis extract on older adults' memory: A randomized controlled trial. Arch Gerontol Geriatr 2018;75:146-50.

66. Beheshti S, Aghaie R. Therapeutic effect of frankincense in a rat model of Alzheimer's disease. Avicenna J Phytomed 2016;6:468

67. Singh P, Chacko KM, Aggarwal ML, Bhat B, Khandal RK, Sultana S, et al. A-90 day gavage safety assessment of Boswellia serrata in rats. Int J Toxicol 2012;19:273.

68. Basch E, Boon H, Heerema TD, Foppo I, Hashmi S, Hasskarl J, et al. Boswellia: An evidence-based systematic review by the natural standard research collaboration. J Herb Pharmacother 2004;4:63-83.

69. Williamson EM. Major Herbs of Ayurveda. London, United Kingdom: Churchill Livingstone; 2002

70. Du Z, Liu Z, Ning Z, Liu Y, Song Z, Wang C, et al. Prospects of boswellic acids as potential pharmaceutics. Planta Med 2015;81:259-71

71. Skarke C, Kuczka K, Tausch L, Werz O, Rossmanith T, Barrett JS, et al. Increased bioavailability of 11 -keto- $\beta$-boswellic acid following single oral dose frankincense extract administration after a standardized meal in healthy male volunteers: Modeling and simulation considerations for evaluating drug exposures. J Clin Pharmacol 2012;52:1592.

72. Hüsch J, Bohnet J, Fricker G, Skarke C, Artaria C, Appendino G, et al. Enhanced absorption of boswellic acids by a lecithin delivery form (Phytosome $^{\sqrt{ }}$ ) of Boswellia extract. Fitoterapia 2013;84:89-98

73. Riva A, Morazzoni P, Artaria C, Allegrini P, Meins J, Savio D, et al. A single-dose, randomized, cross-over, two-way, open-label study for comparing the absorption of boswellic acids and its lecithin formulation. Phytomedicine 2016;23:1375-82

74. Wanga S, Sua R, Niea S, Suna M, Zhanga J, Wub D, et al. Application of nanotechnology in improving bioavailability and bioactivity of dietderived phytochemicals. J Nutr Biochem 2014;25:363-76.

75. Aqil F, Munagala R, Jeyabalan J, Vadhanam MV. Bioavailability of phytochemicals and its enhancement by drug delivery systems. Cancer Lett 2013;334:133-41

76. Majeed M, Prakash L. Boswellin ${ }^{\circledR}$ CG: Chemistry, Toxicology and Clinical. New Jersey: Sabinsa Corporation; 2007.

77. Finney-Brown T. The cosmetic benefits of boswellic acid. Aust J Herb Med 2010;22:63-4. 